\title{
EFFECT OF SOME NATURAL SWEETENERS ON YOGHURT WITH FRUIT (KUMQUAT) DURING STORAGE
}

\author{
MOUSA, RAYA A. S., HALA A. ABD EL-RAHMAN AND \\ FATMA H.M. EL-MASSRY
}

Food Tech. Res. Ins., ARC, Cairo, Egypt

(Manuscript received 14 December 2010 )

\begin{abstract}
The study aimed to produce low calorie yoghurt by using natural sweeteners i.e. sucrose, fructose, stevia and their mixes supplemented with kumquat puree. Kumquat fruit is the source of beta-caroteine, vitamin $\mathrm{C}$ and minerals such as calcium, potassium and magnesium. In addition fermented milk (yoghurt) can supply the human with all natural compounds as well as therapeutic values.

Sucrose (s), fructose (f) and stevia (st) were used as separately and three mixes of (s)+(f) $(1: 1 \mathrm{w} / \mathrm{w}),(\mathrm{s})+(\mathrm{st})(1: 1 \mathrm{w} / \mathrm{w})$ and $(f)+(s t)(1: 1 \mathrm{w} / \mathrm{w})$ respectively to sweetene yoghurt with fruit (zabado).

Physical, chemical, microbiological analysis and sensory evaluation were carried out after preparation and during storage periods of yoghurt with fruit (kumquat).

The results indicated that the yoghurt with fruit (kumquat puree) and sweetened with sucroses had the lowest moisture $78.2 \%$ and carotein $85.46 \mathrm{mg} / 100 \mathrm{gm}$ while the sample sweetened with $100 \%$ stevia recorded the lowest value of calories 51.12 and $50.31 \mathrm{k} . \mathrm{cal}$ in zero time and after storage for 14 days at $5 \pm 2{ }^{\circ} \mathrm{C}$ respectively. Sensory evaluation and statisticall analysis showed that there were slightly significant differences between all treatments for flavour (taste and odor), texture, acidity and color. The total score of treatment No. 1 (sucrose), No. 2 (fructose), No. 4 ( $50 \%$ sucrose $+50 \%$ fructose) and No. 5 ( $50 \%$ sucrose + stevia), were the best treatments were treatment No. 6 (50\% fructose +stevia), while the lowest treatment was No. 3 (stevia).

Total count of bacteria was in permissible limit while the lactic acid bacteria, mold and yeasts were slightly increased during storage. On the other hand coliform group was not detected on prepared and stored samples.

Key words: Fruit, yoghurt, low calorie, natural sweeteners, kumquat and sensory characteristics.
\end{abstract}

\section{INTRODUCTION}

Dairy products can supply with all nutritional compounds of milk in a desired state and suitable for all ages. Fermented milk includes labna, fermented beverages and yoghurt. Yoghurt is a great healthy food and it is probably the best known example of a fermented food that provides probiotic lactic acid bacteria (LAB). In addition yoghurt is source of calcium, protein and vitamin B (Vijayalakshmi et. al., (2010). 
Yoghurt with fruit is very suitable for blending with most fruit types because the acid and acetaldehyde in it are compatible with the flavor of fruits and claimed to be able to enhance them. (Saleh et. al., 2004) processed some kinds of stirred yoghurt supplemented with strawberry and fermented with different kinds of microorganisms. The samples were stored for two weeks and they studied the effect of storage period on total count of microorganisms.

Natural sweeteners can be defined as those sweeteners that have a sweet taste and non caloric. It is used to maintain the desirable sweet taste of foods, beverages and pharmaceutical industries as well as non caloric sugar substitute with particular advantage for person suffering from obesity, diabetics, mellitus, heart disease and dental caries (Chalapalhir et. al., 1997).

Stevia is considered as natural and safe sweeteners. Stevia plant leaves have sweet taste 300 times more than sucrose. It is highly stable to heat and acidity. Besides that it is suitable for diabetics and hypoglycemic (Chalapalhi et. al., 1997).

Fructose is often allowed to diabetics since its metabolism does not require insulin. Furthermore and so smaller amounts of fructose are needed for the same sweetness in food products. In addition fructose can also replace sucrose in several foods such as, berverage, ice cream, juices, jam and carbonated beverages.... etc. (Hemmat et. al., 1996).

Kumquat fruits (Fortunella japonica swing ev.) is a small orange fruits. Their flesh is moderately acidic, the rind is thick, tender and sweet. It is rich in vitamin C and carotenoids which considered antioxidant in fruits and vegetables. It is the best defense against diseases and reduce the risk of coronary heart disease, strake and some cancer cases (Mousa, 1998).

The objective of this study is to investigate the possibilities to produce low calorie stirred yoghurt with fruit by using some natural sweeteners substituting sugars.

\section{MATERIALS AND METHODS}

\section{Materials}

Kumquats and sucrose were purchased from local market. fresh caw's milk was obtained from Dairy Dep. Fac. of Agric., Cairo Univ., Giza, Egypt. Pure culture of Str. salivarius sup sp. thermophilus and Lactobacillus delbrueckii sup sp. bulgaricus were obtained from Hansen Laboratories. Stevia and fructose were purchased from the Egyptian Company for milk products and additives. 


\section{1- Preparation of kumquat puree}

Kumquat fruits (Fortunella Japonica swing ev.) were washed, then the seeds were removed. The fruits were extracted in blender and sterilized at $100^{\circ} \mathrm{C}$ for $5 \mathrm{~min}$.

\section{2- Preparation of yoghurt with fruit (low calorie yoghurt)}

Milk cow's was put in a deep bowl and treated thermally at $70^{\circ} \mathrm{C}$ for 10 min. and then cooled to $40^{\circ} \mathrm{C}$ and inoculated with $3 \%$ active subculture of Str. salavarius sup sp. thermophilus and Lactobacillus delbruckii sup sp. bulgaricus and were incubated at $37^{\circ} \mathrm{C}$ until the time at getting thrombus yoghurt, and then left 12 hours after receiving the clot yogurt. The yoghurt sample was stirred after cooling for 24 hour.

The yoghurt was mixed with kumquat puree and sweetened with different sweeteners (sucrose, fructose, stevia and their mixes) in blender for 2 min. as shown in table (1). The yoghurt with fruit was mobilized in white glass bottles $(150 \mathrm{ml})$. the bottles were closed and stored at $5 \pm 2^{\circ} \mathrm{C}$ for 14 days. The samples were analyzed at zero time and after 7 and 14 days respectively.

Table 1. Formula of yoghurt with fruit (kumquat) and sweetened with different levels of sweeteners in grams.

\begin{tabular}{|c|l|c|c|c|c|c|}
\hline Number & \multicolumn{1}{|c|}{ Samples } & yoghurt & kumquat & sucrose & Fructose & Stevia \\
\hline 1 & Sucrose (control) & 100 & 40 & 10 & - & - \\
\hline 2 & Fructose & 100 & 40 & - & 7 & - \\
\hline 3 & Stevia & 100 & 40 & - & - & 0.5 \\
\hline 4 & $50 \%$ sucrose\&50\% Fructose & 100 & 40 & 5 & 3.5 & - \\
\hline 5 & Sucrose\& Stevia & 100 & 40 & 5 & - & 0.25 \\
\hline 6 & Fructose \& Stevia & 100 & 40 & - & 3.5 & 0.25 \\
\hline
\end{tabular}

\section{Methods}

\section{Chemical analysis:}

Yoghurt with fruit was analyzed for moisture, fat, total protein, total sugars, reducing sugars and $\mathrm{pH}$ values according to the methods described in A.O.A.C. (2005). Acetaldehyde and diacetyl were determined as described in Lees and Jago (1970). Beta carotene was determined according to the method described by (Uniel and Gabelman, 1971). 


\section{Physical analysis}

The color of yoghurt with fruit and sweetened with different sweeteners were determined according to Hunter (1958), pH values and total soluble solids (T.S.S) were determined according to the methods described by A.O.A.C (2005).

\section{Microbiological analysis:}

The resultant fermented milk products were microbiologically examined for total bacterial count, mould and yeasts count and coliform group according to American Public Health Assoc. (A.P.H.A.) (1992) and lactic acid bacteria according to Smona and Robinson (1991).

\section{Sensory evaluation:}

Yoghurt with fruit (kumquat) was evaluated for taste and odor, (flavor), texture, acidity and color by panelists of the staff members of dairy and processing of Horticultural Crops and Pastry Res. Dep. Food Tech. Res. Inst., Agric. Res. Cent. The sensory evaluations were determined according to the method described by Blanc and Odet (1981). Statistical analysis was calculated using the methods described by Sendecor and Cochran (1980).

\section{RESULTS AND DISCUSSION}

Physical properties of fresh and blanched kumquat fruit were determined and tabulated in Table (2). Total soluble solids and pH values were $17.42 \%, 3.66$ and $18.33 \%, 3.68$ in fresh and blanched kumquat respectively. From the same table it could be observed that the $L$ values were more higher after processing and all $a$ and $b$ values were indicated that blanching treatment increased the yellowness and redness. This results is good with this reported by Hemmet et. al. (1996) and Mousa (1998). they reported that blanching inactivates enzymes such as pectin esterase which may attack the methyoxyl groups (degree of esterification) of pectin molecules to make them more sensitive to crosslinking with calcium ions.

Table 2. Physical properties of fresh and blanched kumquat fruits

\begin{tabular}{|c|c|c|}
\hline parameters & Fresh & After blanche \\
\hline Total Soluble solids & 17.42 & 18.33 \\
\hline PH values & 3.66 & 3.68 \\
\hline Hunter Lab measurements & & 78.36 \\
\hline L & 72.48 & +19.74 \\
\hline a & +16.5 & +8.23 \\
\hline b & +6.85 & \\
\hline
\end{tabular}

Color was measured by Hunter Lab Values that;
(L) : : lightness
$(+a) \quad: \quad$ redness
(+b) : yellowness 
Data presented in Table (3) showed the effect of blanching on chemical composition of kumquat fruits, it could be noticed that the moisture content was 80.73 and $79.54 \%$ in unblanched and blanched kumquat respectively. From the same table it could be observed that total sugars were higher in blanched kumquat $(16.32 \%)$ than unblanched one (15.64\%). As for protein and ash content they recorded $1.68,0.82 \%$ and $1.69,0.93 \%$, in unblanched and blanched kumquat. On the other hand, ascorbic acid content was $90.38 \mathrm{mg} / 100 \mathrm{gm}$ in unblanched kumquat while it was decreased to $40.82 \mathrm{mg} / 100 \mathrm{gm}$ in blanched kumquat.

Concerning the beta carotene, it could be noticed that blanched kumquat was increased $(192.44 \mathrm{mg} / 100 \mathrm{gm})$, while unblanched kumquat was $(183.50 \mathrm{mg} / 100 \mathrm{gm})$. At the same table it could be noticed that the blanched kumquat had the highest content of potassium (291.45) than the other one, calcium, sodium and magnesium were $250.74,12.33$ and $13.22 \mathrm{mg} / 100 \mathrm{gm}$ in blanched kumquat. These results are in line with the finding of Mousa (1998).

Table 3. Effect of blanching on chemical composition of kumquat fruits (fresh weight).

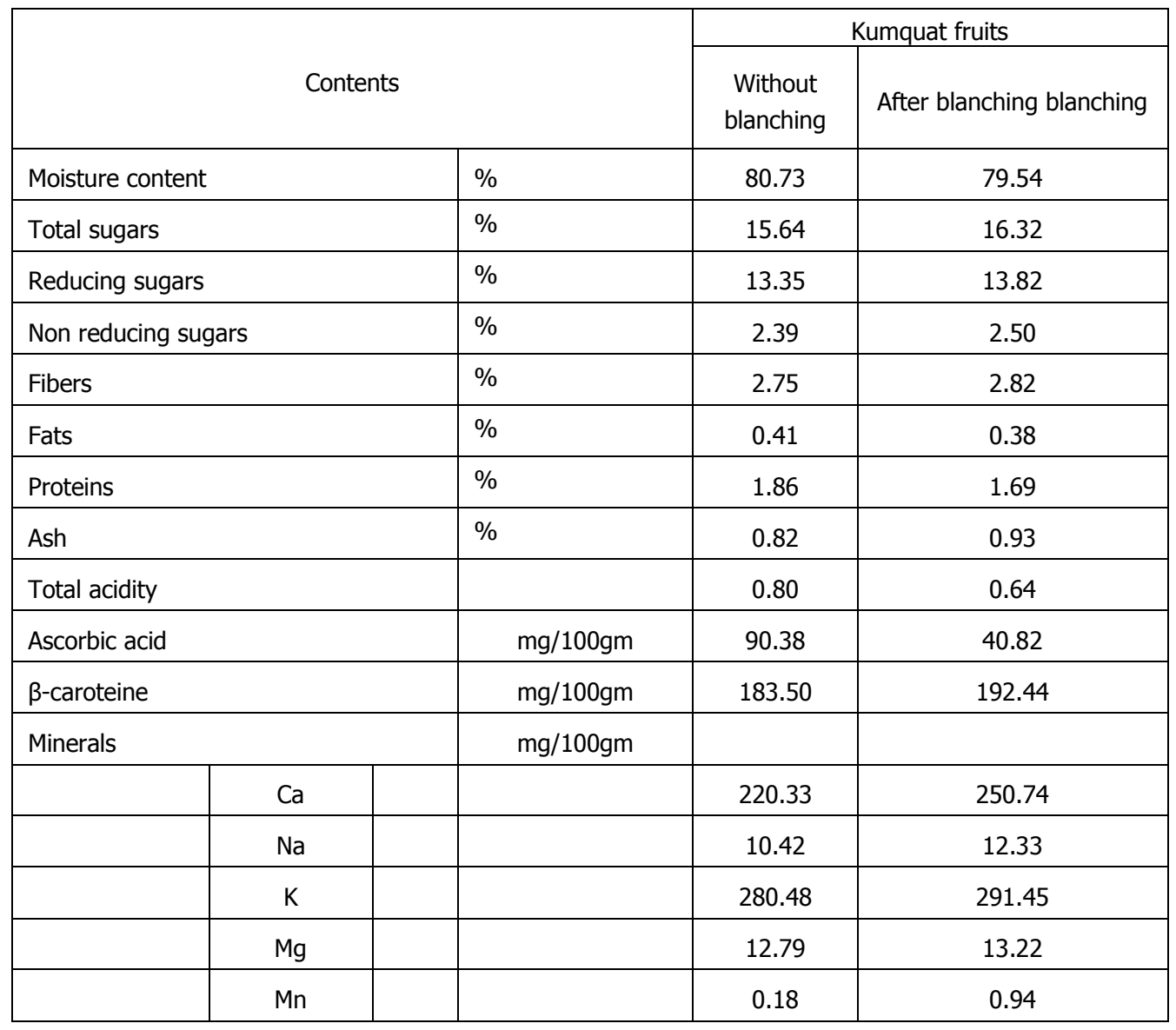


The effect of storage on yoghurt with fruit sweetened with different sweeteners was studied and results given in Table (4) revealed that there were a decrement in moisture content in all the treatments during storage periods. As well as total sugar content was decreased during storage in all treatments. The decrease was $5.46 \%$ in samples sweetened with sucrose. The samples sweetened with stevia had the highest decrements in total sugars $(14.28 \%)$ during storage this is due to utilization of lactose by lactic acid bacteria. When the samples sweetened with (50\% fructose $+50 \%$ stevia) had the lowest values decrements in total sugars $(4.90 \%)$ during storage.

On the other hand, beta carotene was increased in all treatments during storage. Where the treatment No.(6) had the highest increment followed by treatment No. (5) while the treatment No. (1) had the lowest ones. From the same table, it could be noticed that total protein and fat were increased slightly in all treatments during storage periods. This results are in agreement with those reported by Chalapalhi et. al., (1997) and Mona et. al., (2005).

Table 4. Effect of storage for 14 days at $5 \pm 2^{\circ} \mathrm{C}$ on the chemical analysis of yoghurt with kumquat and sweetened with different sweeteners

\begin{tabular}{|c|c|c|c|c|c|c|c|c|c|}
\hline Treatments & Sweeteners & $\begin{array}{l}\text { Storage } \\
\text { period } \\
\text { (days) }\end{array}$ & $\begin{array}{c}\text { Moisture } \\
\%\end{array}$ & $\begin{array}{c}\text { Fat } \\
\%\end{array}$ & $\begin{array}{c}\text { Total } \\
\text { protein \% }\end{array}$ & $\begin{array}{c}\text { Total } \\
\text { sugars } \\
\%\end{array}$ & $\begin{array}{c}\text { Reducin } \\
\mathrm{g} \\
\text { sugars } \\
\% \\
\end{array}$ & $\begin{array}{c}\beta- \\
\text { carotein } \\
\mathrm{e} / \mathrm{mg} \\
100 \mathrm{gm} \\
\end{array}$ & $\begin{array}{c}\text { Calories } \\
\text { values } \\
\text { (K. cal) }\end{array}$ \\
\hline \multirow{3}{*}{$\mathrm{T}_{1}$} & \multirow{3}{*}{ Sucrose } & 0 & 78.2 & 3.45 & 2.83 & 14.64 & 3.25 & 85.46 & 100.93 \\
\hline & & 7 & 77.1 & 3.45 & 2.88 & 14.01 & 3.60 & 87.33 & 98.61 \\
\hline & & 14 & 76.3 & 3.46 & 2.95 & 13.84 & 3.87 & 90.74 & 98.30 \\
\hline \multirow[t]{3}{*}{$\mathrm{T}_{2}$} & \multirow{3}{*}{ Fructose } & 0 & 79.01 & 3.45 & 2.63 & 12.63 & 8.42 & 92.33 & 92.09 \\
\hline & & 7 & 78.31 & 3.5 & 2.82 & 12.40 & 8.65 & 95.42 & 98.066 \\
\hline & & 14 & 77.32 & 3.56 & 2.81 & 12.02 & 8.74 & 98.71 & 98.36 \\
\hline \multirow[t]{3}{*}{$T_{3}$} & \multirow{3}{*}{ Stevia } & 0 & 82.11 & 3.24 & 2. 34 & 3.15 & 1.83 & 94.33 & 51.12 \\
\hline & & 7 & 81.01 & 3.27 & 2.52 & 3.00 & 1.93 & 95.71 & 50.01 \\
\hline & & 14 & 80.64 & 3.31 & 2.92 & 2.90 & 1.98 & 96.98 & 50.31 \\
\hline \multirow[t]{3}{*}{$\mathrm{T}_{4}$} & \multirow{3}{*}{$\begin{array}{c}\text { Sucrose } \\
\quad \& \\
\text { Fructose } \\
\end{array}$} & 0 & 78.60 & 3.36 & 2.52 & 13.14 & 6.4 & 87.33 & 92.88 \\
\hline & & 7 & 77.33 & 3.38 & 2.64 & 13.01 & 6.6 & 87.65 & 92.02 \\
\hline & & 14 & 76.81 & 3.42 & 2.64 & 12.15 & 6.74 & 90.72 & 89.82 \\
\hline \multirow[t]{3}{*}{$T_{5}$} & \multirow{3}{*}{$\begin{array}{c}\text { Sucrose } \\
\& \\
\text { Stevia } \\
\end{array}$} & 0 & 80.43 & 3.33 & 2.33 & 8.64 & 2.5 & 95.41 & 73.85 \\
\hline & & 7 & 79.60 & 3.33 & 2.33 & 8.52 & 2.79 & 98.33 & 73.37 \\
\hline & & 14 & 77.31 & 3.34 & 2.34 & 8.13 & 3.14 & 102.74 & 72.94 \\
\hline \multirow[t]{3}{*}{$\mathrm{T}_{6}$} & \multirow{3}{*}{$\begin{array}{c}\text { Fructose } \\
\& \\
\text { Stevia }\end{array}$} & 0 & 80.74 & 3.34 & 2.34 & 7.83 & 5.72 & 98.72 & 70.74 \\
\hline & & 7 & 79.01 & 3.40 & 2.40 & 7.61 & 6.01 & 99.34 & 70.64 \\
\hline & & 14 & 77.93 & 3.46 & 2.46 & 7.44 & 6.42 & 101.51 & 70.42 \\
\hline
\end{tabular}


The acetaldehyde and diacetyl content of yoghurt with fruits as affected by using different natural sweeteners is shown in Table (5). Results indicated that yoghurt with kumquat and sweetened with different natural sweeteners caused a decrease in acetaldehyde and increase in diacetyl during storage for 14 day at $5 \pm 2^{\circ} \mathrm{C}$. This decrease in acetaldehyde was proportional to the kind of sweeteners. In general, the levels of acetaldehyde of all treatments including control (100\% sucrose) were decreased during storage periodincluding control (100\% sucrose) were decreased during storage period (14 days). At the end of storage period, the acetaldehyde was decreased and the acetyl was increased during storage including control. This decrement in acetaldehyde may be attributed to decrease in carbonic compound in yoghurt by the end of storage period (Tamime and Robinson, 1997). This results are in agreement with those reported by (Esawy et. al., 2005).

Table 5. Effect of storage at $5 \pm 2^{\circ} \mathrm{C}$ on the diacetyl and acetaldehyde contents of yoghurt with fruit and sweetened with different sweeteners (mg/100gm).

\begin{tabular}{|c|c|c|c|c|}
\hline Treatments & Sweeteners & $\begin{array}{l}\text { Storage period } \\
\quad \text { (days) }\end{array}$ & Diacetyl & Acetaldehyde \\
\hline \multirow{3}{*}{$\mathrm{T}_{1}$} & \multirow{3}{*}{ Sucrose } & 0 & 80.34 & 40.08 \\
\hline & & 7 & 85.32 & 38.13 \\
\hline & & 14 & 90.31 & 35.08 \\
\hline \multirow{3}{*}{$\mathrm{T}_{2}$} & \multirow{3}{*}{ Fructose } & 0 & 78.38 & 38.92 \\
\hline & & 7 & 84.48 & 36.01 \\
\hline & & 14 & 88.33 & 33.32 \\
\hline \multirow{3}{*}{$T_{3}$} & \multirow{3}{*}{ Stevia } & 0 & 74.66 & 37.84 \\
\hline & & 7 & 79.72 & 28.67 \\
\hline & & 14 & 84.33 & 24.33 \\
\hline \multirow{3}{*}{$\mathrm{T}_{4}$} & \multirow{3}{*}{$\begin{array}{l}\text { Sucrose } \\
\& \\
\text { Fructose }\end{array}$} & 0 & 88.45 & 38.01 \\
\hline & & 7 & 91.33 & 35.25 \\
\hline & & 14 & 95.82 & 33.41 \\
\hline \multirow{3}{*}{$T_{5}$} & \multirow{3}{*}{$\begin{array}{c}\text { Sucrose } \\
\& \\
\text { Stevia }\end{array}$} & 0 & 75.82 & 38.00 \\
\hline & & 7 & 85.34 & 35.09 \\
\hline & & 14 & 87.73 & 32.73 \\
\hline \multirow{3}{*}{$\mathrm{T}_{6}$} & \multirow{3}{*}{$\begin{array}{c}\text { Fructose } \\
\& \\
\text { Stevia }\end{array}$} & 0 & 77.64 & 37.74 \\
\hline & & 7 & 81.34 & 35.85 \\
\hline & & 14 & 86.35 & 31.58 \\
\hline
\end{tabular}

Change in $\mathrm{pH}$ of yoghurt with fruit (kumquat) prepared with sucrose or anther sweeteners during storage for 14 days at $5 \pm 2^{\circ} \mathrm{C}$ are graphically presented in Table (6). It could be seen that the treatments had gradually decreased $\mathrm{pH}$ values during storage period. This is due to fermentation of lactose and hydrolysis of protein and fat with formation of volatile substances (Hassan et. al., 1999). This results are in agreement with El-Kholy et. al., (2004). They mentioned that Stevia contained some bacterial agent and fermented Stevia were bactericidal under acidic condition. At the same table, it could be noticed that the yoghurt sweetened with sucrose had the highest values of total soluble solids (T.S.S) $(14.84 \%)$, while the samples sweetened 
with stevia had the lowest values (8.42\%). This is due to the large amounts of added from sucrose in return for very small amounts of stevia which is characterized by high degree of sweet blown up 300 times the sweeteners of sucrose. The total soluble solids (T.S.S) values were slightly increased during storage.

The results in Table (6) also shows the changes in color differences measured by Hunter Lab., during storage of yoghurt with fruit sweetened with different sweeteners. All the tested parameters of Hunter Lab. Difference, i.e. L, a and b were slightly decreased through out storage. These results indicated that as the $L$ value (brightness) of yoghurt with fruit slightly decreased, the color become darker as compared with the fresh one (without storage). Moreover, the (a) value means the redness degree of the prepared yoghurt with fruit (kumquat). The decrement in (a) value means that the yoghurt became pal without shining. In addition the lowest of (b) value reflect the reduction into the color of the prepared yoghurt after 14 days of storage.

Table 6. Effect of storage at $5 \pm 2^{\circ} \mathrm{C}$ on the physical properties of yoghurt fruit (kumquat) and sweetened with different sweeteners.

\begin{tabular}{|c|c|c|c|c|c|c|c|}
\hline \multirow{2}{*}{ Treatments } & \multirow{2}{*}{ Sweeteners } & \multirow{2}{*}{$\begin{array}{l}\text { Storage } \\
\text { period } \\
\text { (days) }\end{array}$} & \multirow{2}{*}{$\mathrm{pH}$} & \multirow{2}{*}{ T.S.S } & \multicolumn{3}{|c|}{ Hunter Lab Measurements } \\
\hline & & & & & $\bar{L}$ & $a$ & $\mathrm{~b}$ \\
\hline \multirow{3}{*}{$\mathrm{T}_{1}$} & \multirow{3}{*}{ Sucrose } & 0 & 4.58 & 19.84 & 82.45 & +10.34 & +4.63 \\
\hline & & 7 & 4.33 & 19.92 & 81.82 & +10.03 & +4.48 \\
\hline & & 14 & 4.11 & 20.13 & 80.34 & +9.62 & +4.32 \\
\hline \multirow{3}{*}{$\mathrm{T}_{2}$} & \multirow{3}{*}{ Fructose } & 0 & 4.56 & 19.68 & 84.53 & +8.43 & +3.91 \\
\hline & & 7 & 4.41 & 19.73 & 82.74 & +7.82 & +3.80 \\
\hline & & 14 & 4.32 & 19.98 & 81.81 & +6.53 & +3.41 \\
\hline \multirow{3}{*}{$\mathrm{T}_{3}$} & \multirow{3}{*}{ Stevia } & 0 & 4.01 & 8.42 & 80.33 & +8.98 & +4.81 \\
\hline & & 7 & 3.92 & 8.83 & 81.34 & +8.97 & +4.15 \\
\hline & & 14 & 3.82 & 8.92 & 82.48 & +7.74 & $+4 . .01$ \\
\hline \multirow{3}{*}{$\mathrm{T}_{4}$} & \multirow{3}{*}{$\begin{array}{l}\text { Sucrose } \\
\& \\
\text { Fructose }\end{array}$} & 0 & 4.45 & 19.73 & 86.45 & +11.34 & +6.33 \\
\hline & & 7 & 4.33 & 19.88 & 85.38 & +10.84 & +6.11 \\
\hline & & 14 & 4.28 & 20.01 & 83.72 & +10.03 & +5.75 \\
\hline \multirow{3}{*}{$T_{5}$} & \multirow{3}{*}{$\begin{array}{c}\text { Sucrose } \\
\& \\
\text { Stevia }\end{array}$} & 0 & 4.46 & 13.14 & 82.52 & $8.23+$ & +4.33 \\
\hline & & 7 & 4.23 & 13.27 & 80.34 & +7.61 & +4.11 \\
\hline & & 14 & 4.01 & 13.63 & 79.33 & $7.00+$ & +3.81 \\
\hline \multirow{3}{*}{$\mathrm{T}_{6}$} & \multirow{3}{*}{$\begin{array}{c}\text { Fructose } \\
\& \\
\text { Stevia }\end{array}$} & 0 & 4.45 & 13.05 & 86.37 & +8.33 & +5.46 \\
\hline & & 7 & 4.33 & 13.13 & 85.21 & $8.21+$ & +5.22 \\
\hline & & 14 & 4.12 & 13.27 & 84.38 & $7.42+$ & 5.11 \\
\hline
\end{tabular}

$$
\begin{array}{lll}
\mathrm{L} & : & \text { lightness } \\
+\mathrm{a} & : & \text { redness } \\
+\mathrm{b} & : & \text { yellowness }
\end{array}
$$

T.S.S : total soluble solids 
Microbial count of fresh and stored yoghurt with fruit (kumquat) and sweetened with different sweeteners were tabulated in Table (7). the results showed that the total count and lactic acid bacteria were in permissible limit. Mold and yeasts were not detected in fresh samples but number of colonies were found in yoghurt with fruit after storage for 14 days at $5 \pm 2{ }^{\circ} \mathrm{C}$, this is due to good hygienic condition during manufacture and storage. Mona et. al., (2005) obtained similar results for ice cream and stirred yoghurt with mango and strawberry.

Thus, it is evident that the pasteurization followed by storage at low temperature would be sufficient to keep the samples for two weeks, stevia inhibits the growth and reproduction of some bacteria and other infections organisms including bacteria that cause tooth decay and gum disease Meyer and Riha (2002). and Mona et. al., (2005).

Table 7. Effect of storage at $5 \pm 2^{\circ} \mathrm{C}$ on the microbial count $(\mathrm{CFU} / \mathrm{mL})$ of yoghurt with kumquat and sweetened with different sweeteners

\begin{tabular}{|c|c|c|c|c|c|c|}
\hline Treatments & Sweeteners & $\begin{array}{c}\text { Storage } \\
\text { period }\end{array}$ & $\begin{array}{l}\text { Total } \\
\text { count } \\
\left(10^{7}\right)\end{array}$ & $\begin{array}{c}\text { Lactic acid } \\
\text { bacterial } \\
\left(10^{6}\right)\end{array}$ & $\begin{array}{c}\text { Moulds } \\
\text { \&Yeasts } \\
\left(10^{1}\right)\end{array}$ & $\begin{array}{c}\text { Coliform } \\
\left(10^{1}\right)\end{array}$ \\
\hline \multirow{3}{*}{$\mathrm{T}_{1}$} & \multirow{3}{*}{ Sucrose } & 0 & 14.5 & 7.5 & N.D & N.D \\
\hline & & 7 & 20.0 & 9.4 & 9.0 & N.D \\
\hline & & 14 & 18.0 & 10.6 & 10.0 & N.D \\
\hline \multirow{3}{*}{$T_{2}$} & \multirow{3}{*}{ Fructose } & 0 & 9.0 & 4.0 & N.D & N.D \\
\hline & & 7 & 12.0 & 6.0 & 8.0 & N.D \\
\hline & & 14 & 10.0 & 6.8 & 9.0 & N.D \\
\hline \multirow{3}{*}{$\mathrm{T}_{3}$} & \multirow{3}{*}{ Stevia } & 0 & 4.0 & 2.2 & N.D & N.D \\
\hline & & 7 & 6.0 & 2.6 & 2.1 & N.D \\
\hline & & 14 & 5.0 & 2.9 & 3.0 & N.D \\
\hline \multirow{3}{*}{$\mathrm{T}_{4}$} & \multirow{3}{*}{$\begin{array}{l}\text { Sucrose } \\
\qquad \& \\
\text { Fructose }\end{array}$} & 0 & 11.0 & 5.0 & N.D & N.D \\
\hline & & 7 & 12.0 & 5.5 & 10.0 & N.D \\
\hline & & 14 & 11.5 & 6.0 & 11.0 & N.D \\
\hline \multirow{3}{*}{$T_{5}$} & \multirow{3}{*}{$\begin{array}{c}\text { Sucrose } \\
\& \\
\text { Stevia }\end{array}$} & 0 & 8.5 & 4.5 & N.D & N.D \\
\hline & & 7 & 11.5 & 5 & 7.0 & N.D \\
\hline & & 14 & 10 & 5.5 & 8.0 & N.D \\
\hline \multirow{3}{*}{$\mathrm{T}_{6}$} & \multirow{3}{*}{$\begin{array}{c}\text { Fructose } \\
\& \\
\text { Stevia }\end{array}$} & 0 & 7.0 & 3.5 & N.D & N.D \\
\hline & & 7 & 8.5 & 4.0 & 5.0 & N.D \\
\hline & & 14 & 6.5 & 4.5 & 6.3 & N.D \\
\hline
\end{tabular}

N.D $=$ Not Detected 
The average score for sensory evaluation of yoghurt with fruit (kumquat) prepared by sucrose replaced by different sweeteners are presented in table (8). Sensory evaluation results as shown in table (8) show slight decrease in taste and odor (flavor), texture and color of yoghurt with fruit (kumquat) during storage. It could be noticed that the yoghurt sweetened with sucrose had the highest values in flavour (taste and odor), texture and color (43, 33 and 9) respectively while the yoghurt sweetened with stevia had the lowest values $(35,28$ and 8) respectively. On the other hand, it could be noticed that the acidity values were increased during storage in all samples for 14 days. Camphell and Cardwell (1990) found that yoghurt containing stevia was not different in flavor scores over all storage times at $4^{\circ} \mathrm{C}$ for 2 , 7 and 14 days. Moussa et. al., (2003) found that low calorie sweet yoghurt can be produced by using stevia sweetener at a concentration $50 \mathrm{mg} / \mathrm{mL}$. there was no significant difference between the mean scores of taste, flavor, texture or acceptability.

Table 8. sensory evaluation of fruit yoghurt which sweetened with different sweeteners and stored for 14 days.

\begin{tabular}{|c|c|c|c|c|c|c|c|}
\hline \multirow[b]{2}{*}{ Treatments } & \multirow[b]{2}{*}{ Sweeteners } & \multirow{2}{*}{$\begin{array}{l}\text { Storage } \\
\text { period }\end{array}$} & \multicolumn{5}{|c|}{ Sensory evaluation } \\
\hline & & & $\begin{array}{c}\text { Taste and } \\
\text { odor } \\
(45)\end{array}$ & $\begin{array}{c}\text { Texture } \\
\text { (35) }\end{array}$ & $\begin{array}{c}\text { Acidity } \\
(10)\end{array}$ & $\begin{array}{l}\text { Color } \\
(10)\end{array}$ & $\begin{array}{c}\text { Total score } \\
(100)\end{array}$ \\
\hline \multirow{3}{*}{$\mathrm{T}_{1}$} & \multirow{3}{*}{ Sucrose } & 0 & 43 & 32 & 6 & 9 & 90 \\
\hline & & 7 & 41 & 32 & 7 & 8 & 88.5 \\
\hline & & 14 & 40 & 30 & 8 & 8 & 86 \\
\hline \multirow{3}{*}{$\mathrm{T}_{2}$} & \multirow{3}{*}{ Fructose } & 0 & 42 & 32 & 8 & 8 & 90 \\
\hline & & 7 & 40 & 30 & 8 & 7 & 85 \\
\hline & & 14 & 38 & 29 & 9 & 7 & 83 \\
\hline \multirow{3}{*}{$\mathrm{T}_{3}$} & \multirow{3}{*}{ Stevia } & 0 & 35 & 28 & 8 & 8 & 79 \\
\hline & & 7 & 34 & 27 & 8.5 & 7 & 76.5 \\
\hline & & 14 & 33 & 25 & 9 & 6 & 73 \\
\hline \multirow{3}{*}{$\mathrm{T}_{4}$} & \multirow{3}{*}{$\begin{array}{c}\text { Sucrose } \\
\& \\
\text { Fructose }\end{array}$} & 0 & 42 & 32 & 7 & 9 & 90 \\
\hline & & 7 & 41 & 31 & 8 & 8 & 88 \\
\hline & & 14 & 40 & 30 & 8.5 & 8 & 86.5 \\
\hline \multirow{3}{*}{$\mathrm{T}_{5}$} & \multirow{3}{*}{$\begin{array}{c}\text { Sucrose } \\
\& \\
\text { Stevia }\end{array}$} & 0 & 37 & 30 & 8 & 9 & 90 \\
\hline & & 7 & 41 & 32 & 7.5 & 8 & 86 \\
\hline & & 14 & 39 & 32 & 7 & 8 & 84 \\
\hline \multirow{4}{*}{$\mathrm{T}_{6}$} & \multirow{3}{*}{$\begin{array}{c}\text { Fructose } \\
\& \\
\text { Stevia }\end{array}$} & 0 & 38 & 31 & 6 & 9 & 83 \\
\hline & & 7 & 36 & 29 & 6.5 & 8.5 & 80 \\
\hline & & 14 & 34 & 26 & 7 & 8 & 75 \\
\hline & L.S.D at 0.05 & & 0.438 & 0.643 & 0.415 & 0.472 & 0.483 \\
\hline
\end{tabular}

In conclusion, it is possible to make fruit yoghurt by replacement about $50 \%$ of sucrose with natural sweeteners without significant effects on yoghurt quality. Also it appears that, sweeteners as natural sources, can be utilized for the production of low calorie yoghurt which are much needed for diabetes especially children and over weight consumers. 


\section{REFERENCES}

1. A. O. A. C. 2005. Official Methods of Analysis. $16^{\text {th }}$ Ed. Associated of Official Analytical Chemists. Inc. Arlington. Virginia. USA.

2. A. P. H. A. 1992. Standard methods for the examination of dairy products American public health. Assoc. Inc. $16^{\text {th }} \mathrm{Ed}$, Washington D.C.

3. Blance, B. and G. Odet. 1981. New monograph on UHT milk appearance, flavour and texture aspects: recent development. Int. Dairy Fed. Bull., 133:25-48.

4. Camphell, B. T. and J. T. Cardwell. 1990. Use of cocoa pulp as a stabilizere and sweetener in sweetened unflavoured yoghurt, J. Dairy Sci., 73:118.

5. Chalopathiri, M. V., S. S. Thimegowda and T.G. Prasad. 1997. Natural non-caloric sweetener stevia (stevia rebaudiana Bertoni) a future crop. Indian 14: 247-350.

6. El-Kholy, A. M., A. M. Goud and A. G. Waffae. 2004. Technological to improve aspects frozen yoghurt quality. Egypt. J. Dairy Sci., 32: 99-110.

7. Esawy, A. F., H. A. Abd El-Rahman and N. H. A. Assem. 2005. Improving the organoleptic properties of some healthy fermented beverages utilization cake production. Food Technology Res. Inst., Agri. Res. Center, Giza, Egypt.

8. Hassan, F. A., W. A. Helmy and A. R. Enab. 1999. Utilization of some local polysaccharide in manufacturing of yoghurt. Egypt J. Dairy Sci., 27: 281-289.

9. Hemmet, I. Matuk, A. M. Ali and K. Sh. Ibrahim. 1996. Chemical and technological studies on production of carrot nectar. Egypt J. Appl. Sci., (9), 74-88.

10. Hunter, R. S. 1958. Photoelectric color difference meter, J. O. Pt. Soc. Am. 84, (12), 985. C.F "Quality control for the food industry" Kramer, A. and Twigg, B. A. Eds. AVI Publishing company ,INC (1970), Third Edition page31.

11. Lees, G. J. and G. R. Jago. 1970. The estimation of diacetyl in presence of other carbonal compounds. J. Dairy Res.37,129.

12. Meyers, S. and W. F. Riha. 2002. Optimizing sweetener blends for low calorie beverages. Food Tech., 56 (7): 42. 
13. Mona, I. M., Aida S. S. and Nawal N. Z. 2005. Production of low calorie functional foods. $2^{\text {nd }}$ International conf. " Future Trends in Food Science and nutrition" 27-29 Nov. Cairo-Egypt.

14. Mousa, A. S. S. R. 1998. Technological and biological studied on papaya and Kumquat fruits. Thesis ph. D. Food Science and technology Faculty of Agricultural. Cairo University .Egypt

15. Moussa, M. M., A. M. Zeitoun and Mona I. Hassan. 2003. Physiochemical properties of stevia sweeteners as natural low caloric sweeteners. Alex. J. Agric. Res. 48: 61-75.

16. Salah, F. A., S. M. Kamel and N. A. Ibraheim. 2004. Viability and metabolic activity of microcapusulated Bifidobacteria in plain and strawberry stirred yoghurt. Egypt J. Agric. Res. 82 (3).

17. Samona, A. D. and P. K. Robinson. 1991. Enumeration of befidobacterin in dairy products. J. of the Soc. of Dairy Technol. 44.(3). August.

18. Sendecor, G.W. and W. G. Cochran. 1980. Statistical methods $6^{\text {th }}$ Ed ., lowa State University press, Ames., lowa.

19. Tamime, A.Y. and R. K. Robinson. 1997. Yoghurt Science and Technology. (second edition). Wood head publishing Ltd, Cambridge, Englan.

20. Uniel, N. and W. H. Gabelman. 1971. Analytical procedure for detecting caroteoids of carrot roots and tomato fruits. J. Am. Soc. Hortic. Sci., 96:702.

21. Vijayalakshmi, R., C. Nareshkumar and B. Dhanalakshmi. 2010. Storage studies of cereal based low fat fruit yoghurt. Egyptian J. Dairy 38:51-61. 


\section{تأثير استخلام بعض المحليات الطبيعية علي الخصائص الكيمائئة والحسيه للزبادي المدعم بفاكهة الكمكوات (الزبادو)}

ريه علي سبد موسي ، هالة عبد المنعم عبد الرحمن ، فاطمة حسن محمد المصري

$$
\text { معرُ بحوث تكنولوجيا الاغنية - مركز البحوث الزراعبة }
$$

تهدف هذه الدراسة لانتاج زبادي بالفو اكه منخفض الطاقة ( زبادو) باستخدام بعض المحليات

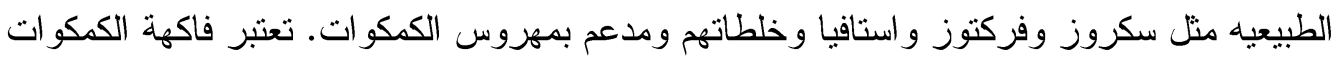
مصدر للبيتاكاروتين وفيتامين C وبعض المعادن مثل الكالسيوم و البوتاسيوم و المغنسيوم بالإضافة

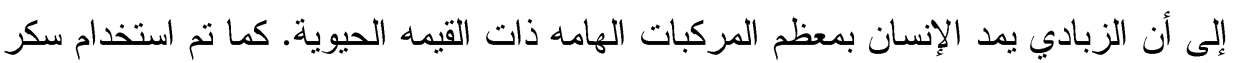
السكروز (س) و الفركتوز (ف) و الاستافيا (أس) كل على حده بجانب خلطاتهم (سكروز +فركتوز

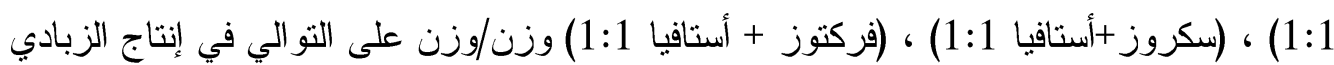

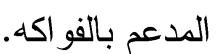

تمت التحاليل الطبيعية و الكيماوي و الميكروبيولوجية و التقيم الحسى بعد التصنيع مباشرة و أثناء التخزين.

أثبتت النتائج أن الزبادي بالفاكهة المحلى بالسكروز كان اقل محتوى في الرطوبة حيث

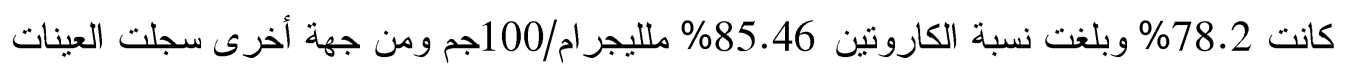
المحلاة بالاستافيا بنسبة (62.43 ، 65.68 كيلو كالورى) وذللك بعد التصنيع مباشرة وبعد التخزين لمدة 14 يوم على التو الي. أظهرت النتائج الحسية والاحصائية عدم وجود فروق معنوية بين جميع المعاملات من

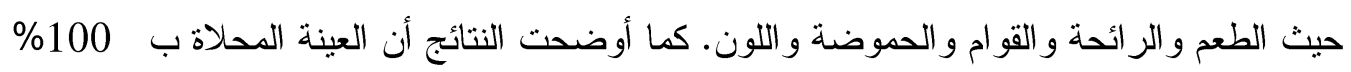
سكروز كانت أفضل النتائج يليها العينة المعاملة بالسكروز و الاستافيا بنسبة ( 1:1) بينما كانت العينات المحلاة بو اسطة الاستافيا 100\% كانت اقلهم في الخصائص سابقة الذكر.

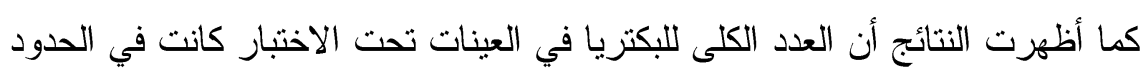

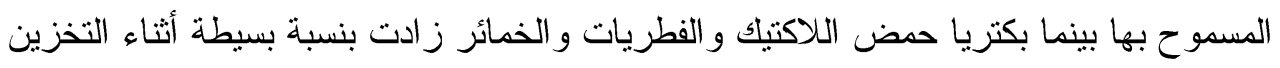
ومن جهة أخرى كانت العينات خالية تماما من بكتريا القولون. 